\title{
Nickel in forests - a short review on its distribution and fluxes
}

\author{
Panagiotis Michopoulos*
}

H.A.O. DEMETER-Institute of Mediterranean Forest Ecosystems, Terma Alkmanos, Athens 115 28, Greece

\begin{abstract}
Michopoulos, P., 2021. Nickel in forests - a short review on its distribution and fluxes. Folia Oecologica, 48 (2): 205-214.

The distribution and cycling of nickel (Ni) in forests is greatly affected by their proximity to emission sources of the metal. The throughfall deposition is always richer in $\mathrm{Ni}$ than the bulk deposition. It can be inferred that some dry deposition enriches the throughfall. In remote forested areas, the hydrological fluxes of Ni do not differ a lot from those in litterfall. In addition, the current year needles in conifers have higher concentrations than the older needles, a sign of absorption and mobility of the metal. In contrast, near an industrial Ni source the older needles accumulate much more of the metal. The Ni content in bark tissue can be used to map the deposition distribution of the metal around an area (rural or urban). The concentrations of $\mathrm{Ni}$ in forest soils is also dependent on their distances from the Ni emission sources and the nature of the soil parent material. The $\mathrm{Ni}$ concentrations increase with soil depth due to the geogenic origin of the metal. Low $\mathrm{pH}$ greatly enhances the mobility of the metal in soils, much more than the leachability of organic matter.
\end{abstract}

\section{Keywords}

forests, hydrology, litterfall, nickel, soil, vegetation

\section{Introduction}

Nickel was established as an essential micronutrient for the growth of temperate cereal crops in 1975 being a component of the enzymes urease and hydrogenase (Dixon et al., 1975). Nickel works as a cofactor to enable urease to catalyze the conversion of urea into the ammonium ion, which plants can use as a source of nitrogen. The activity of hydrogenase provides the ATP necessary for nitrogen reduction into ammonia (DALTON, 1985). Based on these criteria, BROwn et al. (1987) argued, in the late 1980s, that nickel is a nutrient essential for plant life. RUTER (2005) found out that the disorder (stunted plants) observed in nurseries of river birch (Betula nigra L.) was due to low supplies of Ni. Wood et al. (2006) reported that the littleleaf disorder of pecan [Carya illinoinensis (Wangenh.) K. Koch] was caused by Ni deficiency. The authors applied foliar application of $\mathrm{Ni}$ and the symptoms disappeared proving in this way the first known example of Ni deficiency in orchard crops. Despite these findings, there has been more concern about the toxicity of $\mathrm{Ni}$ than about deficiency (NIEMINEN et al., 2007). The toxicity of Ni to organisms has been known for a long time and most research on Ni has concentrated largely on its possible effects on plants growing near industrial activities emitting $\mathrm{Ni}$ or on plants growing on serpentine soils derived from ultrabasic igneous rocks (UREN, 1992). In high concentrations, Ni reduces seed germination, root and shoot growth, biomass accumulation, and final production. In addition, $\mathrm{Ni}$ toxicity can cause chlorosis, necrosis and inhibition of various physiological processes (photosynthesis, transpiration) (HASSAN et al., 2019). The interest on the effects of $\mathrm{Ni}$ on forest plants was initially derived from the fact that forest species were often close to industrial sources of

\footnotetext{
*Corresponding author: e-mail:mipa@fria.gr 
Ni. Moreover, there was a broad interest on metal deposition on forest ecosystems. In this context, NIKONOv et al. (2001) examined the cycle of $\mathrm{Ni}$ in a pine forest. ÇAKIR and AKBURAK (2017) examined the concentration and fluxes of $\mathrm{Ni}$ in pure and mixed stands of oak and beech in Turkey. OFFENTHALER et al. (2009) measured the concentration of $\mathrm{Ni}$ in bulk and throughfall deposition in a forest in the Alps in Austria. HAGEMEYER et al. (1994) measured the Ni concentration in beech wood. SAwIDIs et al. (2012) determined the Ni concentration in evergreen species in the area of Attiki, Greece. So far, there has not been information on the thresholds for deficiency or toxicity in forest species. There are excellent reviews on $\mathrm{Ni}$ availability in soils (UrEN, 1992) and general biogeochemistry of $\mathrm{Ni}$ (NiEminen et al., 2007). The aim of this review was a little more specific, i.e. to collect, quote and draw conclusions on Ni distribution and cycling in forests on remote areas or in the vicinity of industrial plants. Ecological regions having ultramafic rocks as soil parent material giving rise to serpentine soils with a very high content of Ni will not be examined. The text will be broken down to the hydrological paths of the metal and its distribution in vegetation and soil.

\section{Hydrological cycle}

The concentrations of $\mathrm{Ni}$ in the bulk deposition is generally low in remote areas. Usually it is below one $\mu \mathrm{g} \mathrm{L}^{-1}$. Close to pollution centers, it can be much higher. In the urban environment of the Izmir city, Turkey, the wet only deposition had an average Ni concentration of $7.4 \mu \mathrm{g} \mathrm{L}^{-1}$ (Muezzinoglu and Cizmecioglu, 2006). In the proximity of a metal smelting industry located at Sudbury, Ontario, the Ni concentration rose high and reached $174 \mu \mathrm{g}$ $\mathrm{L}^{-1}$ in bulk deposition (JeFFrIES and SNYDER, 1981). The $\mathrm{Ni}$ concentration in throughfall even in forests away from industrial activities varies a lot depending on the soil type and its chemical composition. In six forest types in France (Picea abies Karst., Fagus sylvatica L., Abies alba Mill.), GANDors et al. (2010a) found a range of 0.25 to $0.66 \mu \mathrm{g}$ $\mathrm{L}^{-1}$ in bulk deposition and 0.41 to $0.79 \mu \mathrm{g} \mathrm{L}^{-1}$ in throughfall. In all types, the concentrations of $\mathrm{Ni}$ in throughfall were higher than that in the bulk deposition. In agreement with the previous authors, Michopoulos et al. (2018) found a range of $0.12-1.34 \mu \mathrm{g} \mathrm{L}^{-1}$ in bulk deposition and 0.23 to $4.58 \mu \mathrm{g} \mathrm{L}^{-1}$ in throughfall in a Bulgarian fir ( $\mathrm{Ab}$ ies borisii-regis Mattf.) stand in central Greece. HuANG et al. (2011) found a median Ni concentration of $0.48 \mu \mathrm{g}$ $\mathrm{L}^{-1}$ in the bulk deposition and $1.02 \mu \mathrm{g} \mathrm{L}^{-1}$ in throughfall in a Norway spruce forest in Germany. UKonMAANAHO et al. (1998) measured a range of $0.25-2.70 \mu \mathrm{g} \mathrm{L}^{-1}$ in bulk deposition and $0.93-12.3 \mu \mathrm{g} \mathrm{L}^{-1}$ in throughfall in 4 catchments in Finland with mixed forests of Scots pine (Pinus sylvestris L.), Norway spruce (Picea abies Karst.), and deciduous species (mainly Betula spp.). The reason for the throughfall enrichment is probably the dry deposition and not the leaching. Ni is considered medium among metals with regard to its ability to enrich aerosols, which later on can deposit on forests. Other metals (for example As and
Cd) have much greater ability (STEINESS and FrIEDLAND, 2005). After assessing monthly bulk deposition chemistry for two years at Lake Redon, in Central Pyrenees, Spain, BACARDIT and CAMARERo (2009) inferred that nickel had intermediate properties suggesting a balance of both natural and polluting sources.

The concentrations of $\mathrm{Ni}$ in soil solution are usually higher than those in bulk and throughfall deposition. BERGVIST et al. (1989) reviewed the leachability of metals in temperate forest ecosystems. They found that $\mathrm{Ni}, \mathrm{Zn}$ and $\mathrm{Cd}$ were very susceptible to changes in soil acidity. As a result, a gradual release of metals from the mineral soil and an increase in soil solution concentration of metals through the B horizon are characteristic features of acid soils. For this reason when referring to Ni concentrations in soil solution the status of acidity in soils should be given. Equally important are the way of soil solution collection (tension or zero tension lysimeters) and the characterization of soils in terms of texture analysis. In France, in acid sandy soils, GANDOIS et al. (2010b) using suction cups in a silver fir stand found a Ni concentration of $6.75 \mu \mathrm{g} \mathrm{L}^{-1}$ at a depth of $20 \mathrm{~cm}$ and $2.99 \mu \mathrm{g} \mathrm{L}-1$ at the depth of $75 \mathrm{~cm}$. In a Norway spruce forest stand in Germany in an acid sandy loam soil the Ni concentration in soil solution (zero tension lysimeters) had a median of 1.22 at $20 \mathrm{~cm}$ depth and $1.37 \mu \mathrm{g} \mathrm{L}^{-1}$ at $90 \mathrm{~cm}$ depth (HuANG et al., 2011). Higher concentrations $\left(6.82-19.4 \mu \mathrm{g} \mathrm{L}^{-1}\right)$ of $\mathrm{Ni}$ in soil solution extracted with zero tension lysimeters at a depth of $35 \mathrm{~cm}$ in acidic podzol soils were found by UKONMAANAHO et al. (1998) in mixed forests in Finland mentioned above. It is not only $\mathrm{pH}$ that enhances the leaching of $\mathrm{Ni}$ from soils. In Sweden, BergVIST (1987) found that in a brown earth forest (spruce and beech) soil at a depth of $35 \mathrm{~cm}$ the $\mathrm{Ni}$ concentrations in the leachates (zero tension lysimeters) reached a value of $4 \mu \mathrm{g} \mathrm{L}^{-1}$, whereas in a podzol soil the $\mathrm{Ni}$ concentration was $2 \mu \mathrm{g} \mathrm{L}^{-1}$. The podzol soil had higher amounts of organic matter and the author attributed this fact that $\mathrm{Ni}$ is not a metal related to the leaching of humus (like $\mathrm{Cu}, \mathrm{Pb}$ and $\mathrm{Cr}$ ). Table 1 summarizes information about Ni concentrations in the hydrological cycle.

\section{Hydrological and litterfall fluxes}

The hydrological and litterfall fluxes of $\mathrm{Ni}$ refer to the amounts of Ni per unit of area per time that enter or leave a forest ecosystem. Usually they are expressed in $\mathrm{g} \mathrm{ha}^{-1}$ $\mathrm{yr}^{-1}$ but other units are possible. In general in forested areas away from metal smelting industries the Ni fluxes in bulk, throughfall deposition and litterfall do not differ a lot. In the mountain area of Lake Redon in Central Pyrenees mentioned above, the fluxes of $\mathrm{Ni}$ in the bulk deposition ranged from 5.2 to $6.5 \mathrm{~g} \mathrm{ha}^{-1} \mathrm{yr}^{-1}$ (BACARDIT and CAMARERO, 2009). In two holm oak (Quercus ilex L.) forests in Spain, the throughfall fluxes ranged from 7 to $7.3 \mathrm{~g} \mathrm{ha}^{-1}$ $\mathrm{yr}^{-1}$, whereas the bulk deposition $\mathrm{Ni}$ content was below the detection limit (Avila and Rodrigo, 2004). In Germany, in a remote forest of Norway spruce, the Ni fluxes were 5.0, 8.7 and $5.3 \mathrm{~g} \mathrm{ha}^{-1} \mathrm{yr}^{-1}$ for bulk, throughfall deposition and litterfall, respectively. It is worth mentioning 
that the Ni fluxes in throughfall in this forest were higher than those in litterfall. For the soil solution, the fluxes were 11.5 and $8.3 \mathrm{~g} \mathrm{ha}^{-1} \mathrm{yr}^{-1}$ at the depths of 20 and $90 \mathrm{~cm}$, respectively (HUANG et al., 2011). In two forested sites in Finland UKonmananaho et al. (2001) found $2.4 \mathrm{~g} \mathrm{ha}^{-1} \mathrm{yr}^{-1}$ in the litterfall of a Scots pine (Pinus sylvestris L.) stand and $6.2 \mathrm{~g} \mathrm{ha}^{-1} \mathrm{yr}^{-1}$ in the litterfall of a mixed stand of Norway spruce, birch and aspen. In the Northeastern France in the Vosges Mountains, GandoIs et al. (2010b) found rather high fluxes of $\mathrm{Ni}$ in the soil solution, i.e. 43 and $24 \mathrm{~g}$ $\mathrm{ha}^{-1} \mathrm{yr}^{-1}$ at the depths of 20 and $70 \mathrm{~cm}$, respectively. When there is an industrial Ni source, things change. In the area of a smelting center of Ontario in Canada, the bulk deposition fluxes ranged from 74 to $1,560 \mathrm{~g} \mathrm{ha}^{-1} \mathrm{yr}^{-1}$ (JEFFRIES and SNyder, 1981). Derome and Nieminen (1998) examined elemental fluxes at the distances of $0.5,4$ and $8 \mathrm{~km}$ from a $\mathrm{Cu}-\mathrm{Ni}$ smelter in Finland in a Scots pine ecosystem. They found that at the $0.5 \mathrm{~km}$, the bulk deposition fluxes were $600 \mathrm{~g} \mathrm{ha}^{-1} \mathrm{yr}^{-1}$, in the throughfall $1,400 \mathrm{~g} \mathrm{ha}^{-1} \mathrm{yr}^{-1}$ and the solution flux at $40 \mathrm{~cm}$ depth was $500 \mathrm{~g} \mathrm{ha}^{-1} \mathrm{yr}^{-1}$.

\section{Input of Ni to forests through weathering fluxes}

There are not many works on the Ni inputs to forests through weathering. GANDoIs et al. (2010b) applied the Profile model (Sverdup and WARFInge, 1993) to find the weathering of base cations and the ratio of metals to base cations in parent material to find the release of trace metals (PACÈs, 1998). He found a weathering flux of $0.47 \mathrm{~g} \mathrm{ha}^{-1}$ $\mathrm{yr}^{-1}$ in the soil of a silver fir stand. This is a low value, which was attributed to the sandy nature of soils. STARR et al. (2003) used the Zirconium method. Zr mainly occurs in the mineral form $\mathrm{ZrSiO}_{4}$, which is extremely resistant to weathering (TOLE, 1985), and for this reason it can be used as an internal standard to calculate the weathering losses of other elements. They applied the method to podzol soils under Scots pine in eastern Finland. They found higher weathering fluxes for $\mathrm{Ni}$ than the previous authors. More specifically, they found a range of 2.93 to $4.46 \mathrm{~g} \mathrm{ha}^{-1}$ $\mathrm{yr}^{-1}$, which were even higher than the litterfall fluxes in those Scots pine stands. It would be interesting to see future works with this subject in more clayey soils.

\section{Vegetation}

The concentrations of $\mathrm{Ni}$ in plant tissues reflect the distance from a local source of $\mathrm{Ni}$ emissions together with properties of soils. In a remote fir forest Michopoulos et al. (2018) found an average of $3.81 \mathrm{mg} \mathrm{kg}^{-1}$ in current year needles and $2.53 \mathrm{mg} \mathrm{kg}^{-1}$ in second year needles of Bulgarian fir. Higher concentrations of $\mathrm{Ni}$ in current needles $\left(2.3 \mathrm{mg} \mathrm{kg}^{-1}\right)$ than in second year ones $\left(1.7 \mathrm{mg} \mathrm{kg}^{-1}\right)$ were also found by NiKonov et al. (2001) in Scotch pines in Russia in unpolluted areas. GandoIs and Probst (2012) also found a decreasing trend from young needles to older needles $\left(4.7-3.5 \mathrm{mg} \mathrm{kg}^{-1}\right)$ in silver fir in the south of France, in the Pyrenees Mountains. In general, when certain nutrients are deficient in the plant tissue, older leaves are able to translocate them to younger leaves (MAUSETH, 1998). Nutrients with this ability are mobile nutrients, and include $\mathrm{N}, \mathrm{P}, \mathrm{K}, \mathrm{S}$ and $\mathrm{Mg}$. It seems that plants apply this mechanism in an environment deficient in Ni. When the distance to a pollution source become smaller, the concentrations increase in all needle ages. The difference here is that the $\mathrm{Ni}$ concentrations in older needles increases. NiKONOv et al. (2001) found 273 and $396 \mathrm{mg} \mathrm{kg}^{-1}$ in current and second year of Scots pine needles, respectively at

Table 1. Concentrations $\left(\mu \mathrm{g} \mathrm{L}^{-1}\right)$ of $\mathrm{Ni}$ in the hydrological cycle of some forests. In the soil solution the concentrations are inside the parentheses

\begin{tabular}{|c|c|c|c|c|}
\hline Location & Vegetation & Bulk & Throughfall & Reference \\
\hline France & Picea abies & 0.38 & 0.49 & GANDOIS et al. (2010a) \\
\hline France & Fagus sylvatica & 0.25 & 0.45 & GANDOIS et al. (2010a) \\
\hline France & Abies alba & 0.46 & 0.74 & GANDOIS et al. (2010a) \\
\hline Central Greece & Abies borisii regis & $0.12-1.34$ & $0.23-4.58$ & MichOPOULOS et al. (2018) \\
\hline $\begin{array}{c}\text { Finland } \\
\text { (South to North) }\end{array}$ & $\begin{array}{c}\text { Pinus sylvestris, } \\
\text { Picea abies, Betula } \\
\text { sp. }\end{array}$ & $0.25-2.70$ & $0.93-12.3$ & $\begin{array}{c}\text { UKONMAANAHO et al. } \\
\text { (1998) }\end{array}$ \\
\hline Germany (Bavaria) & Picea abies & $0.11-4.16$ & $0.27-11.7$ & HUANG et al. (2011) \\
\hline \multicolumn{5}{|c|}{ Soil solution and depth } \\
\hline South Sweden & Picea abies & $15 \mathrm{~cm}(1.5)$ & $35 \mathrm{~cm} \mathrm{(4.0)}$ & BERGVIST (1987) \\
\hline South Sweden & Fagus sylvatica & $15 \mathrm{~cm}(4.0)$ & $35 \mathrm{~cm}(3.8)$ & BERGVIST (1987) \\
\hline Germany(Bavaria) & Picea abies & $90 \mathrm{~cm}(0.97-3.20)$ & & HUANG et al. (2011) \\
\hline Eastern Finland & Pinus sylvestris & $40 \mathrm{~cm}(2.93-4.40)$ & & STARR et al. (2003) \\
\hline
\end{tabular}


a distance of $8 \mathrm{~km}$ away from a $\mathrm{Cu}-\mathrm{Ni}$ smelter in Russia. In any case, the magnitude of $\mathrm{Ni}$ concentration in unpolluted areas is low and it is high in proximity to pollution sources. In the Sudbury Region (Ontario, Canada), NkonGOLO et al. (2008) found a range of Ni concentration in the needles of black spruce (Picea mariana Mill.) 17.0 to $21.1 \mathrm{mg} \mathrm{kg}^{-1}$, whereas in the control site the respective concentration was $3.48 \mathrm{mg} \mathrm{kg}^{-1}$. In Finland, Derome and NiEMENEN (1998) measured the Ni content in one-year needles of Scots pine at various distances from a $\mathrm{Cu}-\mathrm{Ni}$ smelter. At $8 \mathrm{~km}$, the concentration was 5.08 , at $4 \mathrm{~km} 7.8$ and at $0.5 \mathrm{~km} 43.5 \mathrm{mg} \mathrm{kg}^{-1}$. RAUTIO and HutTUNEN (2003) collected and analyzed needles of Scots pine from plots located along a $350 \mathrm{~km}$-long transect extending from the vicinity of the Monchegorsk smelter complex on the Kola Peninsula, NW Russia, through Finnish Lapland to the Finnish-Swedish border. They found a Ni concentration of $50 \mathrm{mg} \mathrm{kg}^{-1}$ in current year needles and over $100 \mathrm{mg}$ $\mathrm{kg}^{-1}$ in the second year needles of Scots pine close to pollution sources. PARZYCH et al. (2017) determined the Ni concentration in six pine species within the area of the forest at the University botanic garden in the city of Kosice (Slovakia). The concentrations were rather high having a range of 3.5 to $17 \mathrm{mg} \mathrm{kg}^{-1}$. The authors did not mention any source of metal smelting around the area. As the second year needles had higher concentration from the current year ones, some Ni deposition could have taken place. For example, Scots pine had a concentration of $7.3 \mathrm{mg} \mathrm{kg}^{-1}$ in current year needles and $17.1 \mathrm{mg} \mathrm{kg}^{-1}$ in current +1 -year's needles. In addition, the Ni concentrations in the bark was very high (91 $\left.\mathrm{mg} \mathrm{kg}^{-1}\right)$. McGeE et al. (2007) measured low concentrations $\left(0.65-2.47 \mathrm{mg} \mathrm{kg}^{-1}\right)$ of $\mathrm{Ni}$ in broadleaves in Maine, USA (Table 2). However, high concentrations of $\mathrm{Ni}$ can also appear in broadleaves. In the Ukrainian Carpathians, SHPARYK and PARPAN (2004) found $8.5 \mathrm{mg} \mathrm{kg}^{-1}$ in beech leaves and $45 \mathrm{mg} \mathrm{kg}^{-1}$ in oak (Quercus robur L.) leaves located close to a more polluted site.

A question about needle/leaves analysis that arises is to wash or not wash (before analysis). RAUTiO and HuTTUNEN (2003) found that the Ni concentration in the needle wax of Scots pine in the work mentioned above, in the area with the highest deposition (close to smelter) was 20- to over 30 -fold higher than the internal concentrations. When the Ni deposition was low, there was no significant difference between internal and total concentrations in needles. Therefore, a high Ni concentration close to pollution source does not necessarily mean that Ni has entered plant cells. On the other hand washing removes a potential risk to forest plants because the Ni entrance into plant cells can also take place from the needle surfaces. NiEminen et al. (2004) found that pine seedlings grown in unpolluted soil could absorb $\mathrm{Ni}$ through deposition from a nearby $\mathrm{Cu}-\mathrm{Ni}$ smelter. In the author's opinion, both analyses are useful to draw conclusions with regard to Ni toxicity.

Apart from the leaf/needle tissues, the trunk wood and the trunk bark present special interest. Schelle et al. (2008) used the bark tissue of 642 tree species to map the deposition of $\mathrm{Ni}, \mathrm{Cd}$ and $\mathrm{As}$ in the area of Sheffield, UK. They found that the concentrations of $\mathrm{Ni}$ and $\mathrm{Cd}$ were greatest close to a large steel works, their probable source, and declined markedly within $500 \mathrm{~m}$ of it and from there more gradually over several kilometers. In contrast, trunk wood accumulates elements mainly from the soil and its metal concentration does not reflect the atmospheric pollution (Rossini Oliva and Mingorance, 2006). In the trunk wood of a sugar maple (Acer saccharum Marsh.) stand in Ontario, USA, Morrison and Hogan (1986) found higher concentrations of $\mathrm{Ni}\left(0.5 \mathrm{mg} \mathrm{kg}^{-1}\right)$ with regard to $\mathrm{Cd}\left(0.19 \mathrm{mg} \mathrm{kg}^{-1}\right)$ and $\mathrm{Pb}\left(0.3 \mathrm{mg} \mathrm{kg}^{-1}\right)$. МiCHOPOULOS et al. (2018) found $0.501 \mathrm{mg} \mathrm{kg}^{-1}$ in the trunk bark and $0.277 \mathrm{mg} \mathrm{kg}^{-1}$ in the trunk wood of a Bulgarian fir. Lower concentrations $\left(0.05 \mathrm{mg} \mathrm{kg}^{-1}\right)$ in the trunk wood were found by GANDOIs et al. (2010b) but similar ones in the bark $\left(0.58 \mathrm{mg} \mathrm{kg}^{-1}\right)$ of a mature silver fir (Abies alba Mill.) stand. The ratio of the metal concentrations in tree bark over the respective one in wood was used as an indication of atmospheric pollution (Rossini OLIVA and MiNGORANCE, 2006). GANDOIS et al. (2010b), however, argued that this ratio should be used with caution as in remote and unpolluted forests the increased metal concentrations in tree barks might be due to metal leaching from canopy and not directly from the atmosphere.

Table 2 is a concise source of information with regard the $\mathrm{Ni}$ concentrations in needles/leaves as well as wood and bark of some forest species.

\section{Soils}

When dealing with heavy metals in soils, the method of determination is important. The reason is that the fractions from which the metals come from and consequently their concentrations differ. The real total metal concentration is attained by digestion with $\mathrm{HF}$ acid, fusion with $\mathrm{Na}$ bicarbonate or Li metaborate and the use of X-Ray Fluorescence. The so called "pseudo total" concentrations is carried out by extraction with concentrated $\mathrm{HNO}_{3}, \mathrm{HCl}$, $\mathrm{HClO}_{4}$ acids or aqua regia $\left(1: 3 \mathrm{HNO}_{3}: \mathrm{HCl}\right)$. There are also the chelating agents (EDTA, DTPA and organic acids of low molecular weight) which extract metals (supposedly the bioavailable ones) from the soil organic fraction or the clay one. The metal concentrations of the latter method is lower than the others. NYGÅRD et al (2012) carried out a large survey with regard to distribution of 32 elements (extracted with $\mathrm{HNO}_{3}$ ) in organic surface soils in Norway. They classified $\mathrm{Ni}$ as an element markedly affected by local pollution sources rather than by transboundary pollution. In a region in northern Norway close to two Russian smelters they found $6.65 \mathrm{mg} \mathrm{kg}^{-1}$, whereas in the other areas (11 in total) the $\mathrm{Ni}$ concentrations ranged 2.55 to $5.43 \mathrm{mg} \mathrm{kg}^{-1}$. In a variety of 23 forested sites in Switzerland, BLASER et al. (2002) found higher concentrations of Ni (determined with X-Ray Fluorescence). The highest concentrations were found in soils derived from limestones and sedimentary rocks $\left(44-60 \mathrm{mg} \mathrm{kg}^{-1}\right.$ in the organic horizons and $64-159 \mathrm{mg} \mathrm{kg}^{-1}$ in the deeper mineral horizons). In a remote forest soil over flysch, Michopoulos et al. (2018) found similar concentrations, using aqua regia and $\mathrm{HF}$ acid as digests, in the FH layer $\left(44 \mathrm{mg} \mathrm{kg}^{-1}\right)$. In the mineral horizons the Ni went increasing with depth and 


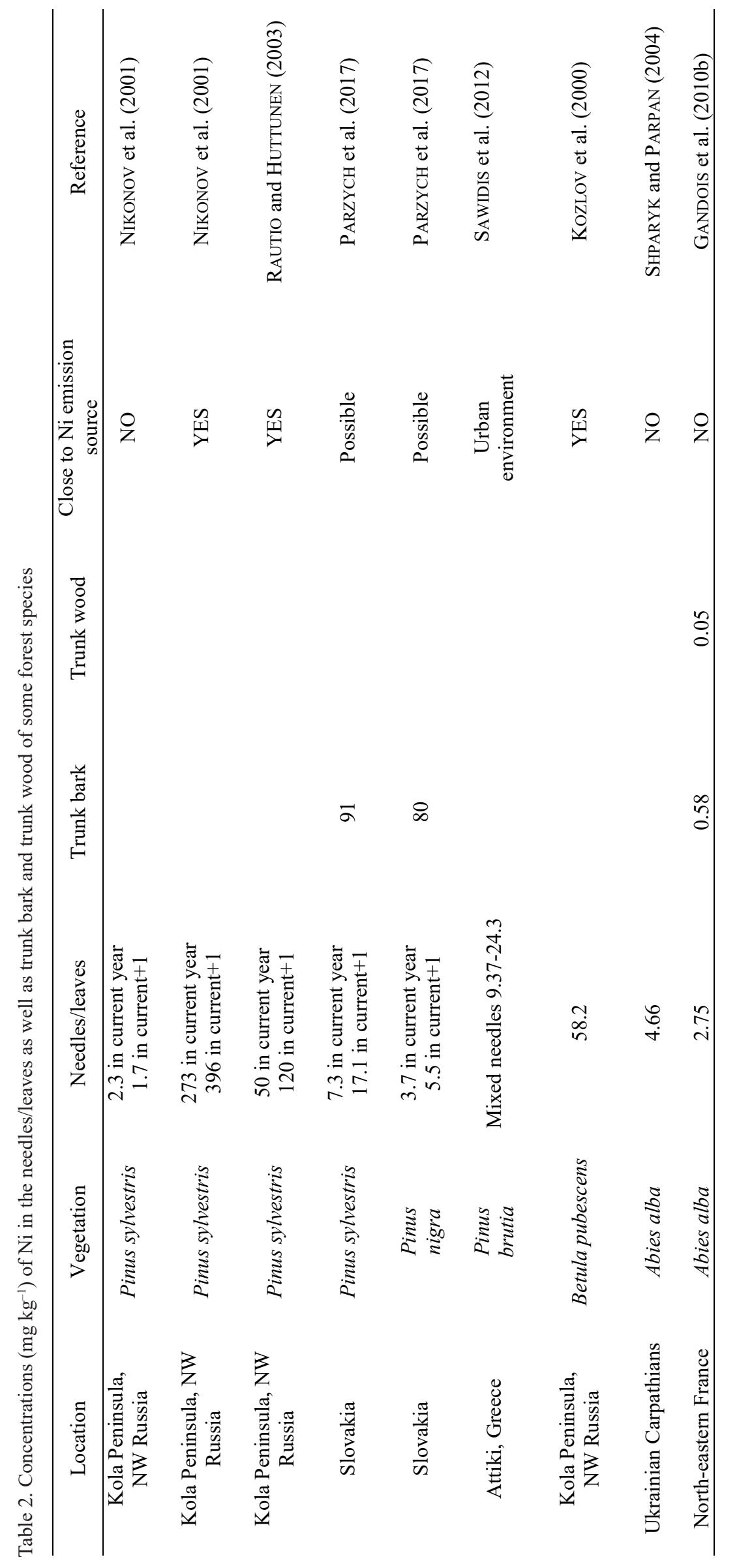




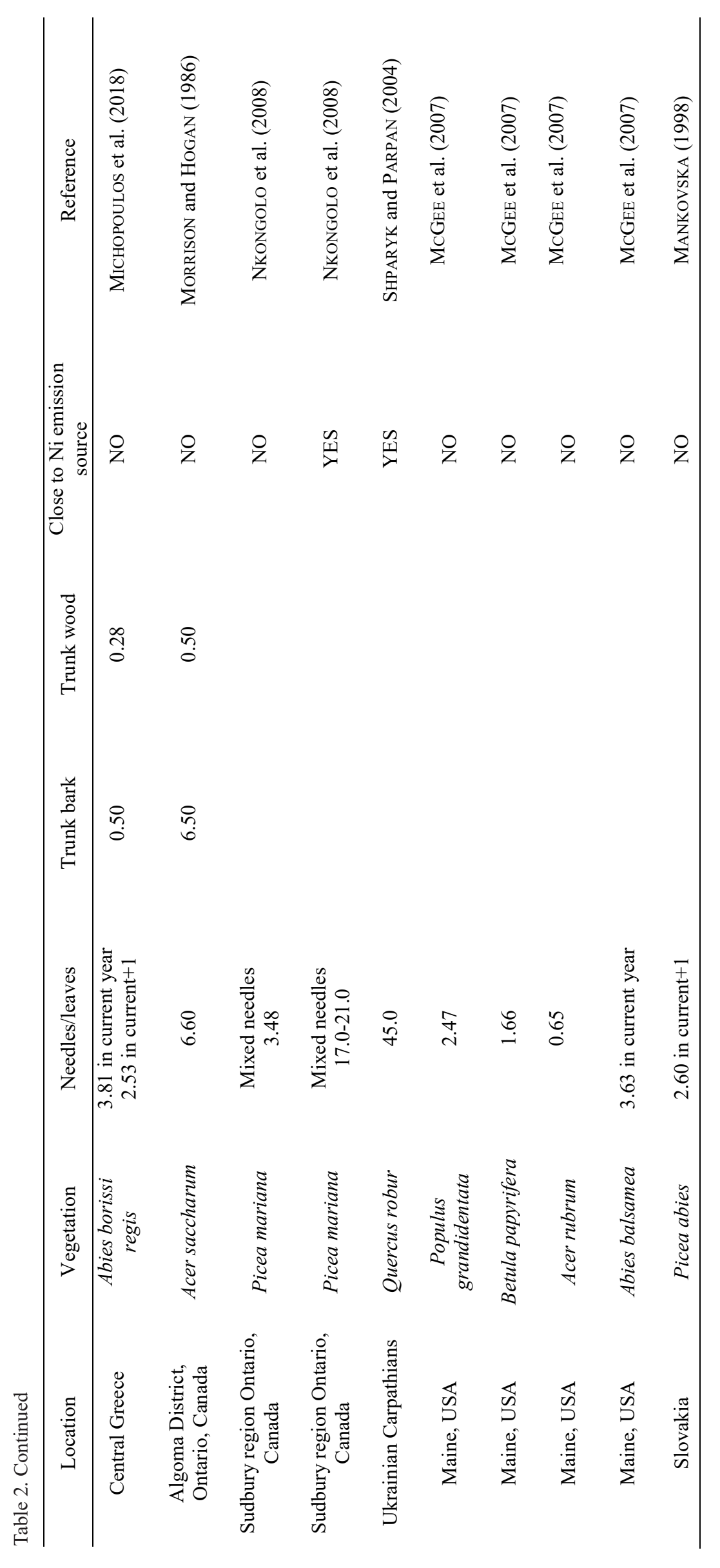




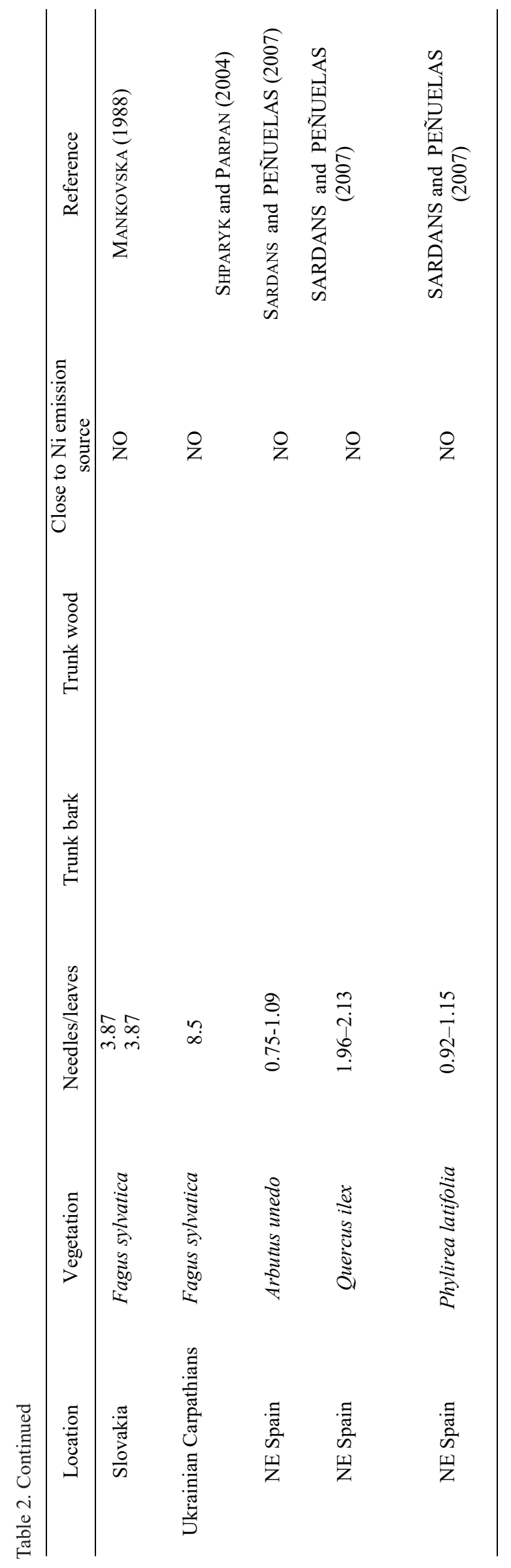


reached $73 \mathrm{mg} \mathrm{kg}^{-1}$ in the $40-80 \mathrm{~cm}$. MutSCH et al. (1996) also found increasing concentrations of $\mathrm{Ni}$ (extracted with $\mathrm{NH}_{4}^{+}$-acetate-EDTA) with soil depth in an area in the Austrian Alps having limestone as a soil parent material. The concentrations ranged from 6.0 to $30 \mathrm{mg} \mathrm{kg}^{-1}$ in forest floors and 26 to $82 \mathrm{mg} \mathrm{kg}^{-1}$ in the mineral horizons. HeRNANDEZ et al. (2003) used a mixture of $\mathrm{HNO}_{3} / \mathrm{HF} / \mathrm{HClO}_{4}$ as digesting agents and found similar concentrations in forest soils derived by marl in France (53-73 $\mathrm{mg} \mathrm{kg}^{-1}$ ). In soils over sandstones, $\mathrm{Ni}$ concentrations are low. GANDOIS et al. (2010b) extracted heavy metals with a mixture of $\mathrm{HF} / \mathrm{HClO}_{4}$ and found a Ni range of $2.38-6.38 \mathrm{mg} \mathrm{kg}^{-1}$ in forest sandy soils the northeastern part of France. The pattern of increasing concentrations of $\mathrm{Ni}$ with depth is due to the geogenic origin of this metal. Together with $\mathrm{Cr}$, the $\mathrm{Ni}$ content in soils has great dependence on the nature of parent material. In forest soils in Germany, the proportions of the variance in the $\mathrm{Ni}$ and $\mathrm{Cr}$ (extracted with aqua regia) concentrations explained by the parent rock type were 43 and $47 \%$, respectively, whereas for $\mathrm{Pb}$ it was $25 \%$ (UTERMANN et al., 2019). The concentrations in the soils in Norway found by NYGÅRD et al. (2012) mentioned above were so low probably because the humus horizon in that cold climate had not any clay particles containing Ni. In soils having acidic parent material, the Ni concentrations were lower. In unpolluted forest soils (podzols) in Poland, ANDERSEN et al. (1994) using aqua regia found 6.1 and $2.1 \mathrm{mg}$ $\mathrm{kg}^{-1}$ of $\mathrm{Ni}$ in the surface (O horizon) and mineral layers, respectively. A little higher value in the forest floor (average $9.2 \mathrm{mg} \mathrm{kg}^{-1}$ ) was found in unpolluted forest soils in 97 sites in Latvia by BRUMELIS et al. (2002), who used $\mathrm{HNO}_{3}$ for digestion. In Poland, CHrzan et al. (2013) found similar concentrations of $\mathrm{Ni}\left(8.0-9.5 \mathrm{mg} \mathrm{kg}^{-1}\right)$ extracted with $\mathrm{HNO}_{3}$ in the surface soils of three forested stands in different distances from Krakow. When forest soils are near a metal smelter, the $\mathrm{Ni}$ concentrations rise abruptly. In central England, WATMOUGH et al. (1995) found a range of $\mathrm{HNO}_{3}$ extractable $\mathrm{Ni}$ of $13-112 \mathrm{mg} \mathrm{kg}^{-1}$ in the $0-10 \mathrm{~cm}$ soil layer. In an urban forest park near Naples in Italy in the surface mineral soils with a volcanic parent material the median $\mathrm{Ni}$ (extracted with a mixture of $\mathrm{HNO}_{3} / \mathrm{HF}$ acids) concentration was $76 \mathrm{mg} \mathrm{kg}^{-1}$ and deeper $(15-20 \mathrm{~cm})$ $88 \mathrm{mg} \mathrm{kg}^{-1}$ (DE Nicola et al., 2003). In a soil survey in the forests of the Czech Republic, Suchara and Sucharoví (2002) used a mixture of $\mathrm{HNO}_{3} / \mathrm{H}_{2} \mathrm{O}_{2}$ and found a range of 6.3 to $53 \mathrm{mg} \mathrm{kg}^{-1}$ of $\mathrm{Ni}$ in the humus layer. They argued that the highest $\mathrm{Ni}$ concentrations were found in the sites where the element had been most accumulated in central Bohemia near steel works. REIMANN et al. (2001) found that $\mathrm{Ni}$ (extracted with aqua regia) had a high spread in both forest floor and $\mathrm{C}$ horizon in forest soils of the Arctic region in Europe. In the first case, the spread was attributed to the existence of local smelters and the in second to the different parent material.

\section{Conclusions}

The existence of Ni smelters can dramatically enhance the concentrations and fluxes of $\mathrm{Ni}$ in forests. In conifer needles, a large quantity of the metal can be trapped by the wax and end up on the forest floor through litterfall. When Ni is in short supply in forest species, the mechanism of translocation is applied to provide new tissues with the metal. In forest soils, Ni can be accumulated in the surface horizon. Unlike other metals $(\mathrm{Cu}$ and $\mathrm{Pb})$, the soil $\mathrm{pH}$ plays a more important role than the organic matter in the metal mobilization and migration further down the soil profile.

\section{Acknowledgements}

The author wishes to thank all researchers who had articles published with regard to the distribution of $\mathrm{Ni}$ in forests. Without their works, the present review would have been impossible.

\section{References}

Andersen, S., ØdegÅrd, S., Rolf, D., Vogt, R.D., Seip, H.M., 1994. Background levels of heavy metals in Polish forest soils. Ecological Engineering, 3: 245-253. https:// doi.org/10.1016/0925-8574(94)90053-1

Avila, A., Rodrigo, A., 2004. Trace metal fluxes in bulk deposition, throughfall and stemflow at two evergreen oak stands in NE Spain subject to different exposure to the industrial environment. Atmospheric Environment, 38: 171-180. https://doi.org/10.1016/j.atmosenv.2003.09.067

Bacardit, M., Camarero, L., 2009. Fluxes of Al, Fe, Ti, Mn, $\mathrm{Pb}, \mathrm{Cd}, \mathrm{Zn}, \mathrm{Ni}, \mathrm{Cu}$, and $\mathrm{As}$ in monthly bulk deposition over the Pyrenees (SW Europe): the influence of meteorology on the atmospheric component of trace element cycles and its implications for high mountain lakes. Journal of Geophysical Research, 114: G00D02.

BergKvist, B., 1987. Leaching of metals from forest soils as influenced by tree species and management. Forest Ecology and Management, 22: 29-56. https://doi. org/10.1016/0378-1127(87)90094-6

Bergkvist, B., Folkeson, L., Berggren, D., 1989. Fluxes of $\mathrm{Cu}, \mathrm{Zn}, \mathrm{Pb}, \mathrm{Cd}, \mathrm{Cr}$, and $\mathrm{Ni}$ in temperate forest ecosystems. Water, Air, and Soil Pollution, 47: 217-286. https:// doi.org/10.1007/BF00279328

Blaser, P., Zimmermann, S., Luster, J., Shotyk, W., 2000. Critical examination of trace element enrichments and depletions in soils: $\mathrm{As}, \mathrm{Cr}, \mathrm{Cu}, \mathrm{Ni}, \mathrm{Pb}$ and $\mathrm{Zn}$ in Swiss forest soils. The Science of the Total Environment, 249: 257-280. https://doi.org/10.1016/S0048-9697(99)005227

Brown, P.H., Welch, R.M., CARY, E.E., 1987. Nickel: a micronutrient essential for higher plants. Plant Physiology, 85:801-803. https://doi.org/10.1104/pp.85.3.801

Brumelis, G., Lapin, L., Nikodemus O., Tabors, G., 2002. Use of the $\mathrm{O}$ horizon of forest soils in monitoring metal deposition in Latvia. Water, Air, and Soil Pollution, 135: 291-309. https://doi.org/10.1023/A:1014714111050

ÇAK R, M., AKBURAK, S., 2017. Litterfall and nutrients return to soil in pure and mixed stands of oak and beech. Journal of the Faculty of Forestry Istanbul University, 67: 
185-200.

Chrzan, A., Formicki, G., Marko-Wortowska, M., 2013. Heavy metals concentration in forest soils. Fresenius Environmental Bulletin, 22: 1993-1996.

Dalton, D.A., Evans, H.J., Hanus, F.J., 1985. Stimulation by nickel of soil microbial urease activity and urease and hydrogenase activities in soybeans grown in a low-nickel soil. Plant and Soil, 88: 245-258.

De Nicola F., Maisto, G., Alfani, A., 2003. Assessment of nutritional status and trace element contamination of holm oak woodlands through analyses of leaves and surrounding soils. The Science of the Total Environment, 311: 191203. https://doi.org/10.1016/S0048-9697(03)00132-3

Derome, G., Nieminen, T., 1998. Metal and macronutrient fluxes in heavy-metal polluted Scots pine ecosystems in SW Finland. Environmental Pollution, 1989: 219-228. https://doi.org/10.1016/S0269-7491(98)00118-3

Dixon, E., Gazzola C., Blakely, R.I., Zerner B., 1975. Jack-Bean urease (E.C.3.5. 1.5.3.). A metalloenzyme. A simple biological role for nickel. Journal of American Chemical Society, 97: 4131-4133.

Gandois, L., Tipping, E., Dumat, C., Probst, A., 2010a. Canopy influence on trace metal atmospheric inputs on forest ecosystems: speciation in throughfall. Atmospheric Environment, 44: 824-833. https://doi.org/10.1016/j.atmosenv.2009.11.028

Gandois L., Nicolas, M., Van der Heijden, G., Probst, A., 2010b. The importance of biomass net uptake for a trace metal budget in a forest stand in north-eastern France. The Science of the Total Environment, 408: 5870-5877.

Gandois, L., Probst, A., 2012. Localisation and mobility of trace metals in silver fir needles. Chemosphere, 87: 204-210.

Hagemeyer, J., Schfifer, H., Breckle, S.W., 1994. Seasonal variations of nickel concentrations in annual xylem rings of beech trees (Fagus sylvatica L.). The Science of the Total Environment, 145: 111-118. https://doi. org/10.1016/0048-9697(94)90301-8

Hassan, M.U., Chattha, M.U., Khan, I., Сhattha, M.B., Aamer, M., Nawaz, M., Ali, A., Khan, M.A.U., Khan, T.A., 2019. Nickel toxicity in plants: reasons, toxic effects, tolerance mechanisms, and remediation possibilities-a review. Environmental Science and Pollution Research, 26: 12673-12688. https://doi.org/10.1007/ s11356-019-04892-x

Hernandez, L., Probst, A., Probst, J.L., Ulrich, E., 2003. Heavy metal distribution in some French forest soils: evidence for atmospheric contamination. The Science of the Total Environment, 312: 195-219. https://doi. org/10.1016/S0048-9697(03)00223-7

Huang, J.H., LGen, G., Matzner, E., 2011. Fluxes and budgets of $\mathrm{Cd}, \mathrm{Zn}, \mathrm{Cu}, \mathrm{Cr}$ and $\mathrm{Ni}$ in a remote forested catchment in Germany. Biogeochemistry, 103: 59-70. https:// doi.org/10.1007/s10533-010-9447-0

JefFries, D.S., SNyder, W.R., 1981. Atmospheric deposition of heavy metals in central Ontario. Water, Air, and Soil Pollution, 15: 127-152. https://doi.org/10.1007/ BF00161248

Kozlov, M.V., Haukioja, E., Bakhtiarov, A.V., StroGANOv, D.N., Zimina, S.N., 2000. Root versus canopy up- take of heavy metals by birch in an industrially polluted area: contrasting behaviour of nickel and copper. Environmental Pollution, 107: 413-420. https://doi.org/10.1016/ S0269-7491(99)00159-1

Mankovska, B., 1998. The chemical composition of spruce and beech foliage as environmental indicator in Slovakia. Chemosphere, 36: 949-953. https://doi.org/10.1016/ S0045-6535(97)10153-9

Mauseth, J.D., 1998. Botany. An introduction to plant biology. Sudbury, Massachusetts: Jones and Bartlett Publishers. 794 p.

McGee, C.J., Fernandez, I.J., Norton, S.A., Stubbs, C.S., 2007. $\mathrm{Cd}, \mathrm{Ni}, \mathrm{Pb}$, and $\mathrm{Zn}$ concentrations in forest vegetation and soils in Maine. Water, Air, and Soil Pollution, 180: 141-153. https://doi.org/10.1007/s11270-006-9257-0

Michopoulos, P., Bourletsikas, A., KaOukis, K., Daskalakou, E., Karetsos, G., Kostakis, M., Thomaidis, N.S., Pasias, I.N., Kaberi, H., Iliakis, S., 2018. The distribution and variability of heavy metals in a mountainous fir forest ecosystem in two hydrological years. Global NEST Journal, 20: 188-197.

Morrison, I.K., Hogan, G.D., 1986. Trace element distribution within the tree phytomass and forest floor of a tolerant hardwood stand, Algoma, Ontario. Water, Air, and Soil Pollution, 31 493-500. https://doi.org/10.1007/ BF00630867

Muezzinoglu, A., Cizmecioglu, S.C., 2006. Deposition of heavy metals in a Mediterranean climate area. Atmospheric Research, 81: 1-16. https://doi.org/10.1016/j.atmosres.2005.10.004

Mutsch, F., 1996. The use of heavy metals detected in the soil as air-pollution indicators on a stemming slope of the Achenkirch Area. Phyton, 36: 145-154.

Nieminen, T.M., Derome, J., SaArsalmi, A., 2004. The applicability of needle chemistry for diagnosing heavy metal toxicity to trees. Water, Air, and Soil Pollution, 157: 269-279. https://doi.org/10.1023/B:WATE.0000038902.10041.69

Nieminen, T.M., Ukonmaanaho, L., Rausch, N., Shotyk, W., 2007. Biogeochemistry of nickel and its release into the environment. Metal Ions in Life Sciences, 2: 1-30. https://doi.org/10.1002/9780470028131.ch1

Nikonov, V., Goryainova, V., Lukina, N., 2001. Ni and $\mathrm{Cu}$ migration and accumulation in forest ecosystems Kola Peninsula. Chemosphere, 42: 93-100. https://doi. org/10.1016/S0045-6535(00)00104-1

Nkongolo, K.K., Vaillancourt A., Dobrzeniecka, S., Mehes, M., Beckett, P., 2008. Metal content in soil and black spruce (Picea mariana) trees in the Sudbury legion (Ontario, Canada): low concentration of arsenic, cadmium, and nickel detected near smelter sources. Bulletin of Environmental Contamination and Toxicology, 80: 107111. https://doi.org/10.1007/s00128-007-9325-1

NygÅRD, T., Steinnes, E., Royse, O., 2012. Distribution of 32 elements in organic surface soils: contribution from atmospheric transport of pollutants and natural sources. Water, Air, and Soil Pollution, 223: 699-713. https://doi. org/10.1007/s11270-011-0895-5

OfFenthaler, I., Dirnböck, T., Grabner, M.T., Kobler, J., Mirtl, M., Riemer, S., 2009. Long-term deposition of trace metals at the integrated monitoring site Zöbel- 
boden. Report, Umweltbundesamt, N.F. 246. Vienna: Umweltbundesamt. $77 \mathrm{p}$.

PACÈs, T., 1998. Critical loads of trace metals in soils: a method of calculation. Water, Air and Soil Pollution, 105: 451458. https://doi.org/10.1023/A:1005016500956

Parzych, A., MochnackÝ, S., Sobisz, Z., KurhaluK, N., Pollákoví, N., 2017. Accumulation of heavy metals in needles and bark of Pinus species. Folia Forestalia Polonica, series A-Forestry, 59: 34-44.

Rautio, P., Huttunen, S., 2003. Total vs. internal element concentrations in Scots pine needles along a sulphur and metal pollution gradient. Environmental Pollution, 122 273-289.

Reimann, C., Kashulina, G., Caritat, P., Niskavaara, H., 2001. Multi-element multi-medium regional geochemistry in the European Arctic: element concentration, variation and correlation. Applied Geochemistry, 16: 759-780. https://doi.org/10.1016/S0883-2927(00)00070-6

Rosssini Oliva, S., Mingorance, M.D., 2006. Assessment of airborne heavy metal pollution by aboveground pant parts. Chemosphere, 65: 177-182. https://doi.org/10.1016/j. chemosphere.2006.03.003

RUTER, J. M., 2005. Effect of nickel applications for the control of mouse ear disorder on river birch. Journal of Environmental Horticulture, 23: 17-20.

Sardans, J., Peñuelas, J., 2007. Drought changes the dynamics of trace element accumulation in a Mediterranean Quercus ilex forest. Environmental Pollution, 147: 567583. https://doi.org/10.1016/j.envpol.2006.10.008

Sawidis, T., Krystallidis, P., Veros, D., Chettri, M., 2012. A study of air pollution with heavy metals in Athens City and Attica Basin using evergreen trees as biological indicators. Biological Trace Element Research, 148:396-408. https://doi.org/10.1007/s12011-012-9378-9

Schelle, E., Rawlins, B.G., Lark, R.M., Webster, R., StatON, I., MCLeOD, C.W., 2008. Mapping aerial metal deposition in metropolitan areas from tree bark: a case study in Sheffield, England. Environmental Pollution, 155: 164-173. https://doi.org/10.1016/j.envpol.2007.10.036

Steiness, E., Friedland, A.J., 2005. Metal contamination of natural surface soils from long- range atmospheric transport: existing and missing knowledge. Environmental Reviews, 14: 169-186.

ShPARYK, Y.S., PARPAN, V.I., 2004. Heavy metal pollution and forest health in the Ukrainian Carpathians. Environmental Pollution, 130: 55-63. https://doi.org/10.1016/j. envpol.2003.10.030
Starr, M., Lindroos, A.J., Ukonmaanaho, L., Tarvainen, T., TANSKANEN, H., 2003. Weathering release of heavy metals from soil in comparison to deposition, litterfall and leaching fluxes in a remote, boreal coniferous forest. Applied Geochemistry, 18: 607-613. https://doi. org/10.1016/S0883-2927(02)00157-9

Sverdrup, H., Warfinge, P., 1993. Calculating field weathering rates using a mechanistic geochemical model PROFILE. Applied Geochemistry, 8: 273-283. https://doi. org/10.1016/0883-2927(93)90042-F

Suchara, I., Sucharová, J., 2002. Distribution of sulphur and heavy metals in forest floor humus of the Czech Republic. Water, Air and Soil Pollution, 136: 289-316.

Tole, M.P., 1985. The kinetics of dissolution of zircon (ZrSiO4). Geochimica et Cosmochimica Acta, 48: 453-458. https://doi.org/10.1016/0016-7037(85)90036-5

Ukonmaanaho, L., Starr, M., Hirvi, J.-P., KoKko, A., LAhermo, P., Mannio, J., Paukola, T., Ruoho-Airola, T., Tanskanen, H., 1998. Heavy metal concentrations in various aqueous and biotic media in Finnish Integrated Monitoring catchments. Boreal Environment Research, 3: 235-249.

Ukonmaanaho, L., Starr, M., Mannio J., Ruoho-Airola, T., 2001. Heavy metal budget for two headwater forested catchments in background areas of Finland. Environmental Pollution, 114: 63-75. https://doi.org/10.1016/S02697491(00)00207-4

UREN, N.C., 1992. Forms, reactions, and availability of nickel in soil. Advances in Agronomy, 48: 141-203. https://doi. org/10.1016/S0065-2113(08)60937-2

Utermann, J., Aydin, C.T., Bischoff, N., Böttcher, J., Eickenscheidt, N., Gehrmann, J., König, N., ScheLer, B., Stange, F., Wellbrock, N., 2019. Heavy metal stocks and concentrations in forest soils. In WeLLBROCK, N., Bolte, A. (eds). Status and dynamics of forests in Germany. Ecological Studies 237. Springer International Publishing, p. 199-229.

Watmough, S.A., Dickinson, N.M., 1995. Dispersal and mobility of heavy metals in relation to tree survival in an aerially contaminated woodland soil. Environmental Pollution, 90: 135-142.

Wood, B.W., Reilly, C.C., NyczePIR, A.P., 2006. Field deficiency of nickel in trees: symptoms and causes. Acta Horticulturae, 721: 83-98.

Received April 23, 2021 Accepted July 6, 2021 